\title{
Forecast increase in invasive rabbit spread into ecosystems of an oceanic island (Tenerife) under climate change
}

\author{
Víctor Bello-Rodríguez (D), ${ }^{1,7}$ Rubén G. Mateo, ${ }^{2,3}$ Loïc Pellissier, ${ }^{4,5}$ Jonay Cubas, ${ }^{1}$ Brian Cooke, ${ }^{6}$ and \\ Juana María González-Mancebo ${ }^{1}$ \\ ${ }^{1}$ Departamento de Botánica, Ecología y Fisiología Vegetal, Plant Conservation and Biogeography Group, Universidad de La Laguna \\ (ULL), Avenida Astrofísico Francisco Sánchez, s/n 38206, San Cristóbal de La Laguna, Santa Cruz de Tenerife, Spain \\ ${ }^{2}$ Departamento de Biología (Botánica), Universidad Autónoma de Madrid, Calle Darwin 2, 28049 Madrid, Spain \\ ${ }^{3}$ Centro de Investigación en Biodiversidad y Cambio Global (CIBC-UAM), Universidad Autónoma de Madrid, Madrid, Spain \\ ${ }^{4}$ Department of Environmental Systems Science, Landscape Ecology, Institute of Terrestrial Ecosystems, ETH Zürich, Zürich, \\ Switzerland \\ ${ }^{5}$ Unit of Land Change Science, Swiss Federal Research Institute WSL, 8903 Birmensdorf, Switzerland \\ ${ }^{6}$ Institute for Applied Ecology, University of Canberra, Canberra, Australian Capital Territory 2601 Australia
}

Citation: Bello-Rodríguez, V., R. G. Mateo, L. Pellissier, J. Cubas, B. Cooke, and J. M. González-Mancebo. 2021. Forecasted increase in invasive rabbit spread into ecosystems of an oceanic island (Tenerife) under climate change. Ecological Applications 31(1):e02206. 10.1002/eap.2206

Abstract. The European rabbit (Oryctolagus cuniculus) is a pest and a conservation problem on many islands, where its heavy grazing pressure threatens many endemic plants with extinction. Previous studies in its native and introduced range have highlighted the high spatial variability of rabbit abundance at local and landscape scales, depending on many factors such as the existence of different habitats. Modeling of the species can be useful to better understand spatial patterns and to prioritize actions, especially in those regions in which rabbits have become invasive. Here, we investigate the distribution of the European rabbit in Tenerife (Canary Islands, Spain), where the species was introduced during the 15 th century and has subsequently changed vegetation composition. Added to the direct effects of rabbits on vegetation, climate change could also have implications for rabbit populations, especially in the alpine ecosystem. To evaluate that, we estimated rabbit abundance in 216 plots randomly distributed on Tenerife island (61 in the alpine ecosystem), modeled the potential current spatial abundance of the species and considered how it might vary under different climate change scenarios. We associated rabbit abundance to a wide selection of abiotic, biotic, and human variables expected to influence rabbit abundance on the island. We found a positive correlation between rabbit abundance and temperature and a negative correlation in the case of precipitation. Hence, according to the models' projections, climate change is expected to enhance rabbit populations in the future. Current higher densities were related to land disturbance and open areas, and a remarkable increase is expected to occur in the alpine ecosystem. Overall, we consider that this study provides valuable information for land managers in the Canary archipelago as it reveals how global warming could indirectly exacerbate the conservation problems of the endemic flora in oceanic islands.

Key words: climate change; conservation; European rabbit; invasive herbivores; oceanic islands; species abundance modeling.

\section{INTRODUCTION}

The European rabbit (Oryctolagus cuniculus) is among the most widespread alien species on the planet (Flux and Fullagar 1992, Lowe et al. 2000). Originally from the Iberian Peninsula and south of France, the species has been able to adapt to many types of ecosystems outside its native range, being currently distributed in the five continents and introduced in more than 800 islands or island groups across the globe (Myers and Parker

Manuscript received 4 March 2020; revised 20 April 2020; accepted 6 May 2020. Corresponding Editor: Aaron J. Wirsing.

${ }^{7}$ E-mail: vbelloro@ull.edu.es
1965, Flux and Fullagar 1992, Lowe et al. 2000). Their impacts are especially severe on islands, where they can lead to a widespread biodiversity loss and become the main cause of threat for many plants (Atkinson 1989, Bowen and Van Vuren 1997, Garzón-Machado et al. 2010, Cubas et al. 2018). On islands, the species is able to persist due to the absence of specialized predators and a high availability of plants lacking traits to counter herbivory (Bowen and Van Vuren 1997, Courchamp et al. 2003, Lees and Bell 2008, Garzón-Machado et al. 2010, Cubas et al. 2019a). As a consequence, rabbits are transforming the landscape in these new habitats, favoring less palatable or even invasive alien plant species while reducing or even exterminating many native and endemic plants (Rodríguez-Piñero and Rodríguez 
Luengo 1993, Chapuis et al. 2004, Cooke and McPhee 2007, Cubas et al. 2018). Due to these negative impacts, interest in monitoring and modeling the abundance of rabbits outside their native range has increased in the last decades (López-Darias and Lobos 2009, Fordham et al. 2012, Kontsiosis et al. 2013). Monitoring is key for developing effective population controls, as rabbit abundance is known to depend on a large number of interactions with environmental and anthropic factors (Blanco and Villafuerte 1993, Calvete et al. 2004, López-Darias and Lobos 2009, Fordham et al. 2012, Kontsiosis et al. 2013, Tapia et al. 2014). Among those factors, climatic variables have particular interest if we take into account that rabbit populations could be largely influenced by climate change (Tablado and Revilla 2012, Fordham et al. 2012), which could alter the current abundance of the species and ultimately have consequences on the local flora.

In the Canary Islands, where rabbits have become naturalized since the Spanish colonization during the 15th century, recent studies have demonstrated their role as effective landscape transformers (Cubas et al., $2019 a$, 2018). After five centuries, the species has succeeded in colonizing all the habitats of the main islands and islets of the archipelago, producing strong effects on the endemic flora (Marrero and Martin 2000, Martín et al. 2003, Kyncl et al. 2006, Cubas et al., $2019 a$, 2018). Simultaneously, climate change has also become obvious on this archipelago in the last decades (Martín et al. 2012, Santana and Martín 2013, Luque et al. 2014), and this could be making environmental conditions more favorable for rabbits. In fact, warming has been particularly intense in the high mountain sectors of the highest island of the archipelago, Tenerife (Martin et al. 2012), where extreme weather during the winter could be a limiting factor for the species, which usually shows preference for warmer areas (Villafuerte and Delibes-Mateos 2002).

The goal of this study is to evaluate the current potential spatial distribution of rabbits on Tenerife and to identify trends for the species in different climate scenarios. Here, going further than previous studies, we focused our interest on a very complex oceanic island, which has the highest elevational gradient of the Canary archipelago (up to $3,715 \mathrm{~m}$ ), as well as wide climatic and environmental variety. This provides a good example to study the factors that influence rabbit abundance outside its native range and also consider likely future trends. We place special emphasis on the alpine ecosystem, which is currently one of the most affected by herbivory and climate change. According to that goal, we (1) measured rabbit abundance in different habitats across Tenerife and considered climatic correlates to determine the importance of variables such as temperature, precipitation, or habitat type and (2) considered various climate change scenarios to predict how rabbit abundance and impact might change in the future.
Complementarily, we discuss the risk that the rabbit represents to endemic plant species in addition to the direct effect of climate change.

\section{Materials ANd Methods}

\section{Study area}

We focused our work on the island of Tenerife (see Fig. 1B), which is the largest and highest of the Canary archipelago $\left(2,034 \mathrm{~km}^{2}\right.$ and $3,715 \mathrm{~m}$ respectively). It harbors a great complexity of ecosystems, the most important being Euphorbia scrubs, laurel cloud forests (wide sense), pine forests, and alpine scrub. Thermo-sclerophyllous woodlands are also present, but they have been reduced to small fragments mixed in most of the cases with succulent scrubs and other disturbed plant formations (Del Arco et al. 2010). As the most populated island of the archipelago, it is also characterized by zones with a very complex human-nature interface, where disturbance related to agriculture, land abandonment, roads, or buildings is present. Climatologically, there are also contrasted differences in a very limited space due to relief and orientation. Mean values of temperature and annual precipitation can vary from above $19^{\circ} \mathrm{C}$ and $50-300 \mathrm{~mm}$ of the coastal semiarid areas to the $13-18^{\circ} \mathrm{C}$ and $500-1,200 \mathrm{~mm}$ of the cloud forests, or the extreme conditions of the alpine ecosystem with mean temperatures ranging from $6^{\circ}$ to $11^{\circ} \mathrm{C}$ and 350 $500 \mathrm{~mm}$ (Del Arco et al. 2006). As global warming is expected to have strong consequences in the alpine ecosystem of the island (Martín et al. 2015), we also investigated separately this area that is located at the central part of the island, including El Teide National Park (189.9 $\mathrm{km}^{2}$, see Fig. 1C), with most of it above $2,000 \mathrm{~m}$ (highest $3,715 \mathrm{~m}$ ).

\section{Sampling methods}

We estimated rabbit abundance (individuals per hectare) on 216 plots randomly distributed on the island of Tenerife (61 in the alpine area) during the springsummer of 2017, corresponding to the peak of the rabbit populations of that year (Cabrera-Rodríguez 2008). Rabbit abundance was estimated by counting pellets in each plot in 150 circular samplings of $0.1 \mathrm{~m}^{2}$ randomly distributed along transects of $500 \mathrm{~m}$ length, and then transformed to number of rabbits per hectare (Mutze et al. 2014, 2016, Rouco et al. 2016). As pellets can remain long periods on the ground, estimating rabbit abundance using this method is reflecting approximately a two-year period (Mutze et al. 2016). To have an approximation of the rabbit abundance during only one year, we also surveyed 60 of our 216 plots using the method of Fernández-de-Simón et al. (2011) and Cubas et al. (2018), which involves removing and counting newly accumulated rabbit feces two months later to estimate rates of deposition in different seasons 


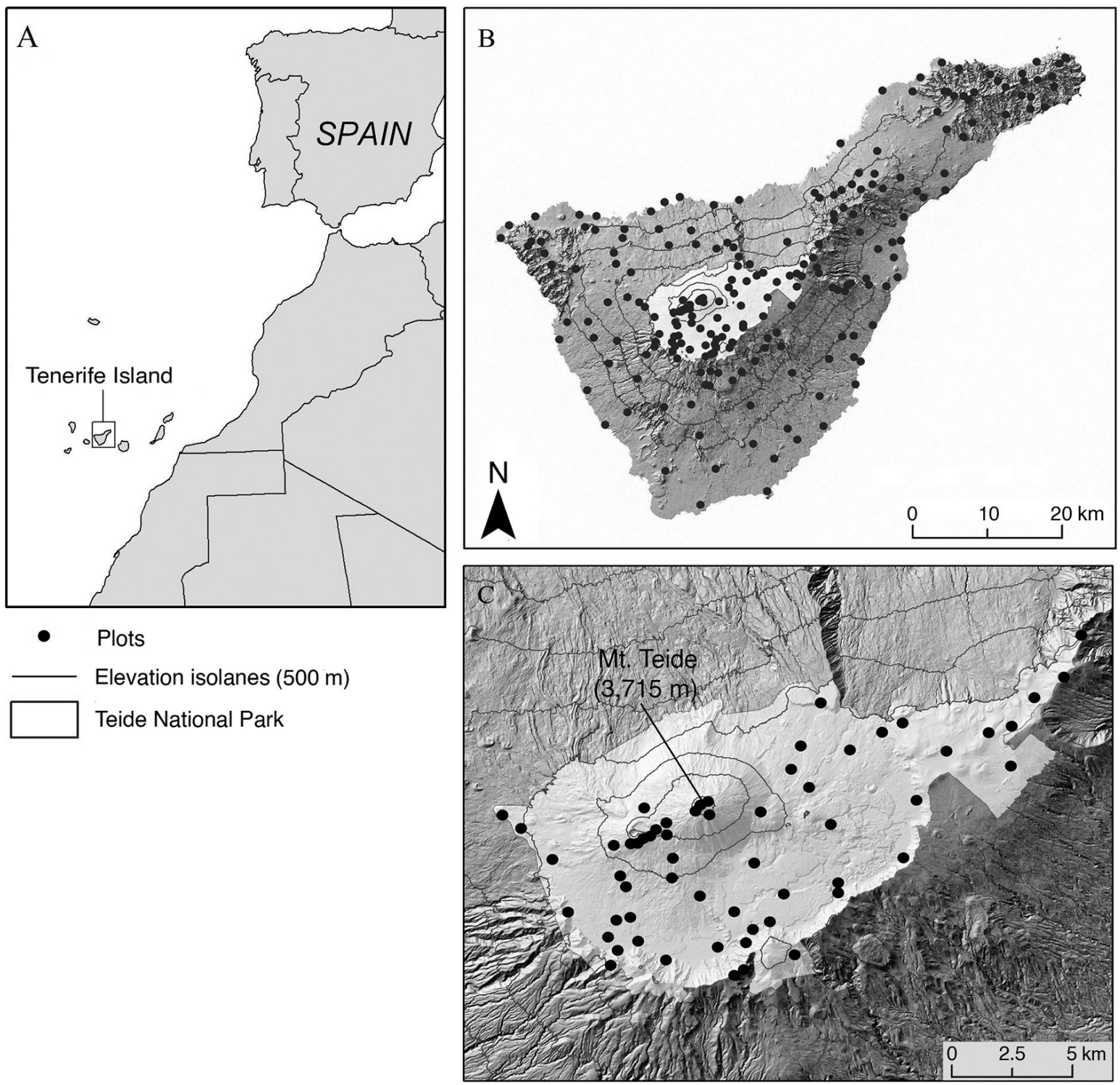

FIG. 1. (A) Study area and localization of inventory plots in (B) Tenerife and (C) the alpine ecosystem.

of the year. This also allowed us to correct feces counts on our plots that were counted only once, as there is a high correlation between the two methods Cubas et al. 2019.

\section{Explanatory variables}

As variables potentially explaining the abundance of the species, we obtained several layers of abiotic, biotic, and human factors at insular and alpine ecosystem scales currently available in public repositories and we simplified or transformed them if necessary in ArcGIS 10.1. All of them (continuous and categorical) were converted in maps covering the areas studied with a pixel resolution of $50 \times 50 \mathrm{~m}$. Climate data were obtained from the temperature and precipitation layers of Santana and Martín 2013 for the island of Tenerife, which already had a resolution of $50 \times 50 \mathrm{~m}$. These layers correspond to data from local meteorological stations that have been generalized to the entire island through regressions and projected to different projections of climate change. In this study, we used the layers for the current scenario and two future scenarios in which temperature increases approximately $1^{\circ}$ and $2^{\circ} \mathrm{C}$, respectively, and precipitation decreases $5 \%$ and $10 \%$. In the case of the alpine ecosystem, we also used a past scenario of $-1{ }^{\circ} \mathrm{C}$ and an increase of $5 \%$ of precipitation with respect to the current scenario, which would approximately correspond to the first half of the 20th century (Santana and Martín 2013), as the anthropic variables used for this 
territory has not changed as much as in the rest of the island (the main road of the area was built between 1918 and 1946). From the vegetation map of Del Arco et al. 2006 we obtained the type of habitat (open or forest areas), type of vegetation (Euphorbia scrub, laurel forest, pine forest, alpine scrub, and disturbed areas) and disturbance (present or not present). Other abiotic variables were also considered, such as elevation, slope, soil hardness, distance to roads, and distance to urban or anthropic areas, which were obtained from several sources detailed in Table 1. For the alpine ecosystem analysis, we used 61 plots located in El Teide National Park and considered only the variables affecting it. Therefore, variables such as disturbance or the information about the rest of the island ecosystems were not included in this model or were adapted as in the case of vegetation type (see Table 1).

\section{Statistical analysis}

To model the potential distribution of the European rabbit, we first performed preliminary models testing different algorithms in an $R$ ( $R$ Core Team 2011) framework: generalized linear models (GLM), generalized additive models (GAM), and Random Forest. In those first models, collinearity analysis between variables (pairwise Pearson correlation analysis) and analysis of variance inflation factor (VIF) were performed to discard highly correlated variables. With the final variable selection, we observed that Random Forest (Breiman 2001) was a better option for our data, with correlations between observed and predicted values above 0.7 , while GLMs and GAMs showed $R^{2}$ values around 0.5 . For the Random Forest models, we ran 100 replicates with a repeated split-sample procedure, and the replicates were fitted on the $70 \%$ data partition, while the other $30 \%$ was used for validation. A maximum of 500 trees and a Poisson distribution (D'Amen et al. 2015, Mateo et al. 2016) were employed. The number of variables used at each split was divided by three since the default option in the randomForest package for $\mathrm{R}$ (Liaw and Wiener 2002) was used. The final model is the average of the 100 replicates. Once we generated the model, we evaluated the general importance of the selected variables using the same package. We also tested the spatial autocorrelation of the residuals of the final model through a Moran's $I$ index $(I)$ in GeoDA 1.14 .0 with 99,999 permutations. We obtained a not significant result for this test $(I=-0.027, P=0.304)$ so we concluded that there was no spatial autocorrelation in our data set. Then, the final model was spatially projected to the whole Tenerife island in order to obtain a map of potential abundance of the species according to the current climate scenario. We then projected to the two before-mentioned future climate scenarios for the whole island and the alpine ecosystem and also to the past scenario only in the latter.

\section{RESULTS}

\section{Rabbit abundance and variables}

Rabbit abundance ranged from a minimum of 0 to a maximum of 16.05 individuals/ha during our field campaign performed in 2017 on Tenerife island. The mean value was 2.22 individuals/ha, with a standard deviation of 2.25 individuals/ha, which suggest that there is a high spatial variability in the abundance of the species. Rabbit abundance estimated on the field and explanatory continuous variables for the entire island revealed a significant and positive influence of temperature and a negative effect for precipitation. The climatic variable that correlated best with rabbit abundance was the maximum temperature of the warmest month. Among the non-climatic variables, elevation, slope, and distance to main roads showed a negative correlation with respect to rabbit abundance. In general, rabbit abundance was higher in areas of low elevation and slope, while the short distance to roads seems to have some positive effect. Other continuous variables considered, such as orientation or distance to urban areas, were discarded due to their low significance. In regard to categorical variables, all of them, except soil hardness, showed a high association with rabbit abundance. We detected that in general, abundance of rabbits was favored by disturbance with a mean value of 3.3 individuals/ha in the disturbed areas and 2.0 individuals/ha in less disturbed areas. The humid areas related to direct influence of the trade winds, showed a low mean value ( 0.76 individuals/ha) but with internal differences. In that altitudinal belt, Fayal-brezal young forests and pine plantations were relatively suitable for rabbits (2.0 individuals/ha vs. 3.2 individuals/ha), while well-preserved laurel forest stands showed the lowest values with a mean of 0.01 individual/ha. We also detected differences between open and shrubby lands (3.0 individual/ ha) when were compared with the whole set of forest ecosystems of this island (0.9 individuals/ha). In regard to the different types of vegetation, again, forest ecosystems showed the lowest mean values ( 0.3 and 1.0 individuals/ha for laurel and pine forest, respectively), while Euphorbia scrub, the alpine ecosystem, and disturbed areas showed higher mean values $(2.9,2.8$, and 3.6 individuals/ha, respectively. Similar trends were found in the alpine ecosystem analysis, with a significant role of elevation, slope, distance to roads (negatively correlated to rabbit abundance), and all the variables related to temperature (positively correlated). The type of vegetation showed differences between areas of Spartocytisus scrub, with higher abundance, and sparse vegetation areas (mean values of 5.9 individuals/ha vs. 1.4 individuals/ha, respectively). Other variables such as annual precipitation or soil hardness were not significant. 
TABLE 1. List of macrovariables considered for modeling rabbit density.

\begin{tabular}{|c|c|c|c|}
\hline Variable & $\begin{array}{l}\text { Type of } \\
\text { variable }\end{array}$ & Detailed description & Source \\
\hline \multicolumn{4}{|l|}{ Abiotic variables } \\
\hline Annual mean temperature & continuous & ${ }^{\circ} \mathrm{C}$ & $\begin{array}{l}\text { Maps from Santana and } \\
\text { Martín (2013) }\end{array}$ \\
\hline $\begin{array}{l}\text { Maximum temperature } \\
\text { of warmest month }\end{array}$ & continuous & ${ }^{\circ} \mathrm{C}$ & $\begin{array}{l}\text { Maps from Santana and } \\
\text { Martín (2013) }\end{array}$ \\
\hline $\begin{array}{l}\text { Minimum temperature } \\
\text { of coldest month }\end{array}$ & continuous & ${ }^{\circ} \mathrm{C}$ & $\begin{array}{l}\text { Maps from Santana and } \\
\text { Martín (2013) }\end{array}$ \\
\hline Annual precipitation & continuous & $\mathrm{mm}$ & $\begin{array}{l}\text { Maps from Santana and } \\
\text { Martín (2013) }\end{array}$ \\
\hline Elevation & continuous & $\mathrm{m}$ & $\begin{array}{l}\text { Digital Elevation Model } \\
\text { from the national } \\
\text { topographic map (BTN25) } \\
\text { of Instituto Geográfico } \\
\text { Nacional (2018) }\end{array}$ \\
\hline Slope & continuous & degrees & $\begin{array}{l}\text { Digital Elevation Model from } \\
\text { the national topographic } \\
\text { map (BTN25) of Instituto } \\
\text { Geográfico Nacional (2018) }\end{array}$ \\
\hline Tradewinds cloud belt & categorical & $\begin{array}{l}\text { Categorized as "cloud belt or not cloud belt" } \\
\text { according to weather the plot is directly affected } \\
\text { or not by the humid layer related to the tradewinds }\end{array}$ & $\begin{array}{l}\text { Map generated in ArcGIS } \\
10.1 \text { from Braojo (2015) data }\end{array}$ \\
\hline $\begin{array}{l}\text { Soil hardness (only in } \\
\text { alpine ecosystem analysis) }\end{array}$ & categorical & $\begin{array}{l}\text { Categorized at landscape scale as "hard soil" when } \\
\text { the area is dominated by all types of lava flows and } \\
\text { "soft soil" when the area is characterized by } \\
\text { sedimentary or pyroclastic materials } \\
\text { or hillside deposits }\end{array}$ & $\begin{array}{l}\text { Map generated in ArcGIS } \\
10.1 \text { from the geological } \\
\text { map of Barrera Morate and } \\
\text { García Moral (2011) }\end{array}$ \\
\hline \multicolumn{4}{|l|}{ Biotic variables } \\
\hline \multirow[t]{5}{*}{ Type of vegetation } & Categorical & Euphorbia scrub $\dagger$ & $\begin{array}{l}\text { Vegetation map from } \\
\text { GRAFCAN } \\
\text { (Del Arco et al. 2006) }\end{array}$ \\
\hline & & Laurel forest (wide sense) $\ddagger$ & \\
\hline & & Pine forest $\S$ & \\
\hline & & Alpine scrub & \\
\hline & & Anthropized areas\# & \\
\hline Type of habitat & Categorical & $\begin{array}{l}\text { Categorized as open areas (including shrubby } \\
\text { vegetation zones or agricultural and abandoned } \\
\text { lands) or forested areas (not differentiating } \\
\text { between Monteverde and pine forest). }\end{array}$ & $\begin{array}{l}\text { Vegetation map from } \\
\text { GRAFCAN } \\
\text { (Del Arco et al. 2006) }\end{array}$ \\
\hline \multirow[t]{2}{*}{$\begin{array}{l}\text { Type of vegetation (only in } \\
\text { alpine ecosystem analysis) }\end{array}$} & Categorical & $\begin{array}{l}\text { Spartocytisus supranubius and } \\
\text { related species scrub }\end{array}$ & $\begin{array}{l}\text { Vegetation map from } \\
\text { GRAFCAN } \\
\text { (Del Arco et al. 2006) }\end{array}$ \\
\hline & & $\begin{array}{l}\text { Open areas with sparse vegetation } \\
\text { (recent pyroclastic materials or lava flows) }\end{array}$ & \\
\hline \multicolumn{4}{|c|}{ Variables related to disturbance and human activity } \\
\hline Distance to main roads & Continuous & $\mathrm{km}$ & $\begin{array}{l}\text { Calculated in ArcGIS from } \\
\text { topographic map of } \\
\text { GRAFCAN (2012) }\end{array}$ \\
\hline Distance to urban areas & Continuous & $\mathrm{km}$ & $\begin{array}{l}\text { Calculated in ArcGIS from } \\
\text { vegetation and topographic } \\
\text { maps (Del Arco et al. 2006, } \\
\text { GRAFCAN 2012) }\end{array}$ \\
\hline $\begin{array}{l}\text { Distance to anthropic } \\
\text { areas (urban areas, } \\
\text { crops, etc.) }\end{array}$ & Continuous & $\mathrm{km}$ & $\begin{array}{l}\text { Calculated in ArcGIS from } \\
\text { vegetation and topographic } \\
\text { maps (Del Arco et al. 2006, } \\
\text { GRAFCAN 2012) }\end{array}$ \\
\hline
\end{tabular}


TABLE 1. (Continued)

\begin{tabular}{cccc}
\hline \hline Variable & $\begin{array}{c}\text { Type of } \\
\text { variable }\end{array}$ & Detailed description & Source \\
\hline Disturbance & Categorical & $\begin{array}{l}\text { Categorized as disturbed or not disturbed, } \\
\text { considering if it constitutes the type of natural } \\
\text { vegetation that corresponds to that area or, on } \\
\text { the contrary, it is composed by transformed } \\
\text { lands or substitutional plant formations }\end{array}$ & $\begin{array}{c}\text { Vegetation map } \\
\text { (Del Arco et al. 2006) }\end{array}$ \\
\hline
\end{tabular}

${ }^{\dagger}$ Includes relatively well-preserved areas of the endemic Euphorbia scrubs of the island (mainly the associations Ceropegio fuscaeEuphorbietum balsamiferae and Periploco laevigatae-Euphorbietum canariensis and other related associations). It goes from the coast to approximately $800 \mathrm{~m}$, and it is characterized by low rates of precipitation. This category also includes fragments of the currently very reduced thermo-sclerophyllous forest.

*Includes those forests from the plant association Lauro novocanariensis-Perseetum indicae and its drier, hygrophilous, edaphic, and most degraded related associations. All of them are to a greater or lesser extent affected by the humid cloud belt of the tradewinds.

${ }^{\S}$ Includes the current distribution of the areas dominated by the endemic Pinus canariensis (main association Sideritido solutaePinetum canariensis), which are located surrounding the highest peak of the island at altitudes around $800-2,400 \mathrm{~m}$. It includes natural pine forests and plantations.

"Includes the island endemic associations Spartocytisetum suprabubii, Erysimo scoparii-Pterocephaletum lasiospermi, Telinetum spachianae, and Violetum cheiranthifoliae, going from the $2,400 \mathrm{~m}$ to the peak of the Teide stratovolcano $(3,715 \mathrm{~m})$. It is characterized by being an open plant formation able to withstand extreme weather conditions.

${ }^{\#}$ We mainly reunited here transformed, agricultural, and abandoned lands.

\section{Random Forest model}

According to these results and after avoiding collinearity between variables, the final model of the entire island included mean annual temperature, maximum temperature of the warmest month, annual precipitation, slope, disturbance, type of vegetation, habitat, and distance to the main roads (see Appendix S1: Fig. S1). With this model, we obtained an absolute mean error of \pm 1.11 individuals/ha, which, considering the maximum of the dependent variable, is relatively low. We obtained a high correlation $\left(R^{2}=0.825, \quad P<0.01\right)$ between the observed and predicted values. In the alpine ecosystem, the final selection of explanatory variables was reduced to mean annual temperature, type of vegetation, slope, and distance to roads with an absolute mean error of \pm 1.36 and a correlation of 0.762 $(P<0.01)$. In the current scenario, the species presented a higher abundance in the lower areas of the island (under $800 \mathrm{~m}$ ) and at the summit (above 2,000 m) coinciding with open ecosystems or, in the first, case also with disturbed areas. On the other hand, the minimum values are located in mid-range elevations coinciding with forests and on the highest areas of El Teide Mountain (above $3,000 \mathrm{~m}$ ).

A general increasing trend in rabbit abundance was forecast along the different climate scenarios (see Figs. 2 and 3) at both the entire island and the alpine area. Overall, rabbit abundance was always significantly higher when we individually compared one scenario with the previous one $(P<0.001$ in Kruskal-Wallis pair comparisons). According to these results, mean rabbit abundance in the whole island increases from the current 2.25 individuals/ha by $5.8 \%$ (future 1) and a $5.9 \%$ (from future 1 to future 2) (Table 2). That increase is not equally distributed on the whole island, as a maximum increase was obtained in the disturbed areas, where the mean rabbit abundance is expected to increase in 9.9\% and $9.8 \%$, respectively, in the two future scenarios. It is followed by the Euphorbia scrub, which increases in $6.4 \%$ and $5.3 \%$ in the two future scenarios and alpine ecosystem with an increment of $4.0 \%$ in the first scenario. Even in the laurel forests, the model predicts increases $(5.4 \%$ and $12.4 \%)$, but in this case, the values still remain very low (near to 1 individual/ha) because of low densities at the present time. The pine forest is the only ecosystem with an apparent decreasing trend in rabbit abundance with a decrease of $6.8 \%$ for the first future scenario and a trend to stabilize on the second one but again remaining generally low.

In the specific model for the alpine ecosystem, values of rabbit abundance were slightly but significantly lower than those obtained by the model for the entire island for this area $(P<0.05 ; 2.05$ individuals/ha vs. 2.24 individuals/ha respectively for the present scenario), although they were highly correlated $\left(R^{2}=0.6\right)$. These differences between both maps are related to the fact of considering some different variables, although the high correlation between them reveals that the main drivers explaining the distribution of the species are present in both models. The model for the alpine ecosystem separately showed a higher increasing trend for rabbit abundance than when the entire island was used, revealing a remarkable ascent of rabbits to higher elevations. Mean values of rabbit abundance increased $25 \%$ from the past scenario (mean value of 1.64 individuals/ha), and continued increasing in $43.4 \%$ and $7.1 \%$ in the two future scenarios, respectively.

\section{Discussion}

Our study highlighted the main factors influencing the distribution of rabbits in the island of Tenerife and forecast trends in abundance under climate change, 
TABLE 2. Mean, maximum (Max), minimum (Min) and standard deviation (SD) values of number of rabbits per hectare obtained from the Random Forests models in the different climatic scenarios in the entire island (by type of vegetation) and in the specific alpine ecosystem analysis.

\begin{tabular}{|c|c|c|c|}
\hline $\begin{array}{l}\text { Type of } \\
\text { vegetation }\end{array}$ & $\begin{array}{l}\text { Current } \\
\text { scenario }\end{array}$ & $\begin{array}{c}\text { Future } \\
\text { scenario }+1^{\circ} \mathrm{C}\end{array}$ & $\begin{array}{c}\text { Future } \\
\text { scenario }+2^{\circ} \mathrm{C}\end{array}$ \\
\hline \multicolumn{4}{|l|}{ General } \\
\hline Mean & 2.25 & 2.38 & 2.52 \\
\hline Max & 7.54 & 7.80 & 7.66 \\
\hline Min & 0.16 & 0.28 & 0.47 \\
\hline $\mathrm{SD}$ & 1.01 & 1.15 & 1.25 \\
\hline \multicolumn{4}{|c|}{ Euphorbia scrub } \\
\hline Mean & 2.50 & 2.66 & 2.80 \\
\hline $\operatorname{Max}$ & 6.00 & 5.99 & 5.90 \\
\hline Min & 1.00 & 1.03 & 1.07 \\
\hline SD & 0.65 & 0.68 & 0.7 \\
\hline \multicolumn{4}{|c|}{ Laurel forest (wide sense) } \\
\hline Mean & 0.92 & 0.97 & 1.09 \\
\hline $\operatorname{Max}$ & 2.09 & 2.12 & 2.38 \\
\hline Min & 0.16 & 0.28 & 0.47 \\
\hline SD & 0.18 & 0.22 & 0.21 \\
\hline \multicolumn{4}{|l|}{ Pine forest } \\
\hline Mean & 1.33 & 1.24 & 1.24 \\
\hline $\operatorname{Max}$ & 2.70 & 2.82 & 2.97 \\
\hline Min & 0.50 & 0.48 & 0.49 \\
\hline SD & 0.29 & 0.28 & 0.49 \\
\hline \multicolumn{4}{|c|}{ Alpine ecosystem } \\
\hline Mean & 2.24 & 2.33 & 2.33 \\
\hline Max & 5.86 & 6.59 & 5.74 \\
\hline Min & 0.61 & 0.57 & 0.55 \\
\hline SD & 0.66 & 0.75 & 0.77 \\
\hline \multicolumn{4}{|c|}{ Antrhopized areas } \\
\hline Mean & 3.04 & 3.34 & 3.67 \\
\hline Max & 7.54 & 7.80 & 7.66 \\
\hline Min & 0.85 & 0.97 & 1.04 \\
\hline SD & 1.10 & 1.22 & 1.25 \\
\hline \multicolumn{4}{|c|}{ Alpine ecosystem (separated analysis) } \\
\hline Mean & 2.05 & 2.94 & 3.15 \\
\hline Max & 6.53 & 6.94 & 6.96 \\
\hline Min & 0.78 & 0.76 & 0.70 \\
\hline SD & 0.61 & 0.88 & 0.86 \\
\hline
\end{tabular}

providing a step forward for better understanding the spatial distribution of this invasive species on subtropical islands. Overall, both models (island and alpine ecosystem) point to an improvement of the environmental conditions for this invasive species in the future mainly due to global warming, which ultimately will have deleterious consequences on the native flora of the island. This is particularly worrying in the alpine ecosystem, which is already threatened by the increase in temperature (Del Arco 2008, Del Arco and GarzónMachado 2012, Bello-Rodríguez et al. 2019). Besides, from the past projection, our study reveals that the European rabbit has been increasing its abundance beyond the treeline. Therefore, this invasive species represents a recent invader in the alpine ecosystem of
Tenerife because unlike in other ecosystems of the island, rabbits are still increasing their altitudinal range.

The general positive correlation observed between rabbit abundance with temperature and the negative correlation with precipitation, follow the same pattern described for the Iberian Peninsula according to Blanco and Villafuerte (1993). High temperatures have been described by many previous studies as a positive factor benefiting rabbit abundance (Villafuerte and DelibesMateos 2002, Calvete et al. 2004, Serronha 2014). On the other hand, rabbits tend to be more abundant or have greater survival in dry sites (Blanco and Villafuerte 1993, Trout et al. 2000, Tablado et al. 2012) although locally, rainfall can have a positive effect in warm areas (Blanco and Villafuerte 1993, Cabezas and Moreno 2007). According to the correlations observed and the projections of our models, increases in rabbit abundance due to global warming are expected to be more prominent in areas that currently harbor high values, mainly low elevation areas and the alpine ecosystem. In this latter case, the specific model for this area revealed a clear increasing trend for rabbit abundance. Interestingly, the maps showed how rabbit abundances have increased from the past scenario and they will continue increasing at higher elevation in the future scenarios. This trend is mainly related to the increase in minimum temperature, which has been estimated in $0.18 \pm 0.06^{\circ} \mathrm{C}$ per decade in this ecosystem since 1944 (Martín et al. 2012) and it will continue increasing according to the predictions of Santana and Martín (2013). The increase in temperature results in a lower frequency of ice and snow, so it could be reducing one of the limitations for the reproduction of the species at high elevations (Blanco and Villafuerte 1993, Flux 2001). Rabbits have already been pointed out as the main cause of the regression of the endemic alpine keystone species Spartocytisus supranubius in the last 40 yr (Kyncl et al. 2006, Cubas et al. 2018). They are also provoking remarkable impacts on the rest of the native flora of the alpine ecosystem (Cubas et al. 2019a), which, due to elevational isolation and the almost absence of introduced ruderal and invasive species, it is almost completely composed by endemics (Steinbeuer et al. 2016, Fernández-Palacios et al. 2014). According to our results, it is expected that all these valuable plant species will see reduced populations and distributions as rabbit abundance continues increasing. Something similar can also affect to low elevation areas (under $800 \mathrm{~m}$ ), where the models also predict increasingly high rabbit abundance in future scenarios. In these areas, there is more disturbance (e.g. agricultural or abandoned lands and roads), which according to our data, doesn't have a negative impact on the number of rabbits. Previous studies have already addressed the preference of the species for open and transformed areas (Blanco and Villafuerte 1993, Atkinson and Atkinson 2000, Cabrera-Rodríguez 2006, Regos et al. 2012, Serronha 2014). These disturbed areas are mostly located in these low elevation areas, where the thermo-sclerophyllous forest has almost 


\section{Current scenario}
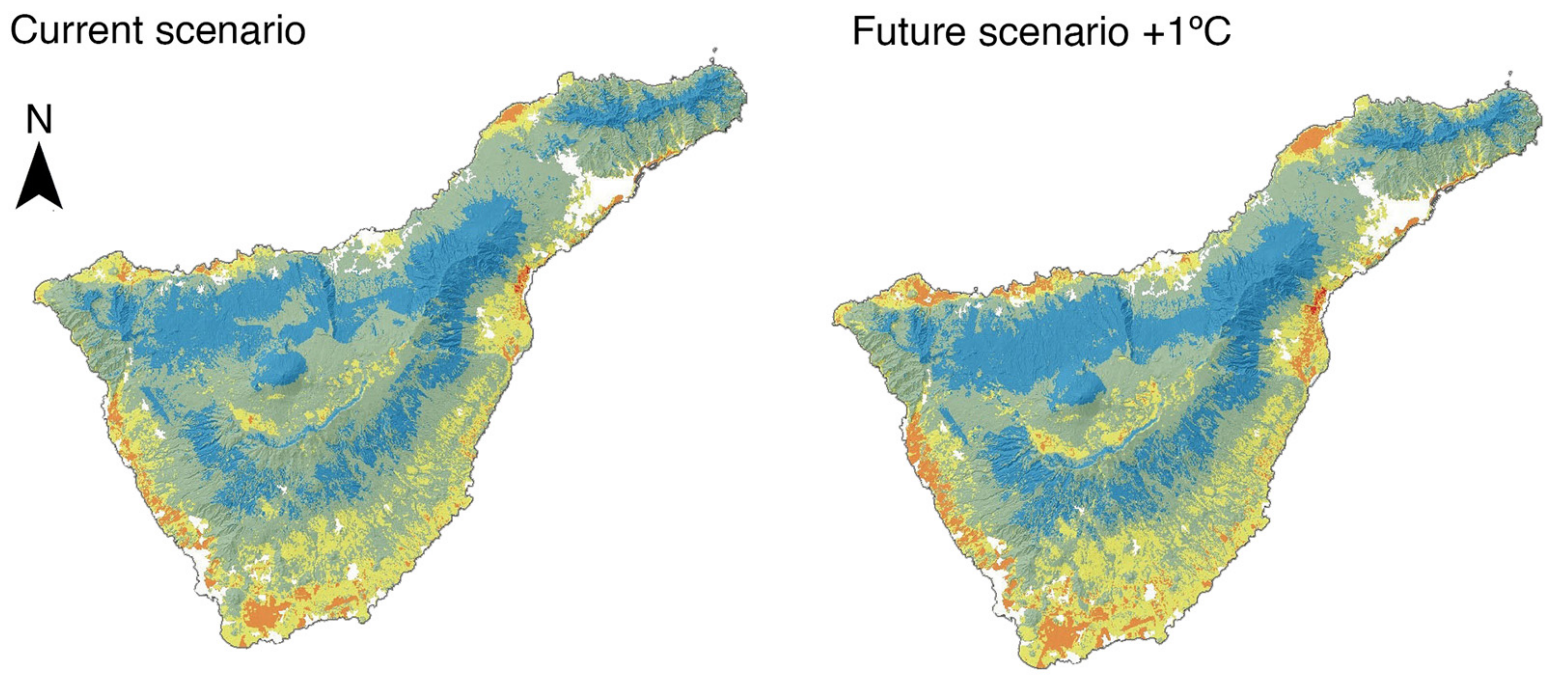

\section{Future scenario $+2^{\circ} \mathrm{C}$}

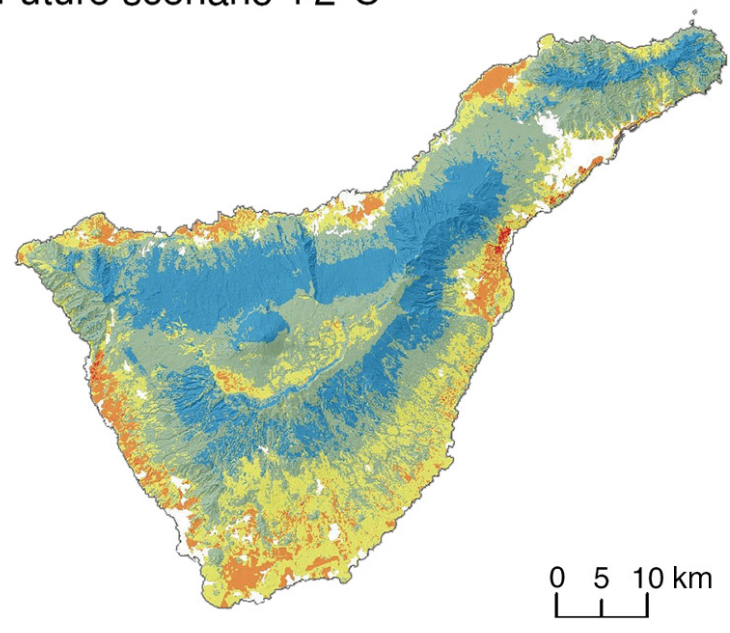

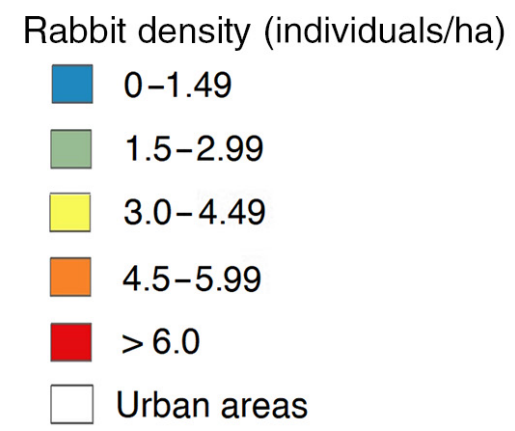

FIG. 2. Spatial distribution of rabbits (individuals/ha) in Tenerife island during 2017 (current scenario) and projections to future scenarios of global warming. [Color figure can be viewed at wileyonlinelibrary.com]

disappeared (Del Arco et al. 2010) and Euphorbia scrubs are being destroyed at a very rapid rate as a consequence of the urbanization process related to tourism that has been taking place since the 1960s (Otto et al. 2007). According to our results, the expected increase in rabbit abundance in the future will exacerbate the already existent ecosystem disturbance due to plant cover loss, especially for endemics, which are more palatable than non-endemic species (Cubas et al., 2019a). Additionally, we found a negative correlation between slope and rabbit abundance. This coincides with previous studies that have demonstrated the preference of the species for relatively flat areas, avoiding the high cover of rocks that may exist in areas of high slope (Calvete et al. 2004, Farfán et al. 2008, Kontsiotis et al. 2013). Therefore, we can expect that topographically complex areas are likely to become even more important in the future for many endemic endangered species that already survive in high-slope areas (Irl et al. 2015).

The high rabbit abundance of low elevation areas and alpine ecosystem contrasts considerably with respect to the low values of the forest areas. Although it is a pattern already known for the species in other forest ecosystems (Atkinson and Atkinson 2000), in Tenerife this can also be attributed to several specific factors rather than just to a preference for low canopy cover areas. On one hand, pine forests in the Canary Islands nowadays show a very low diversity and cover of endemic understory species, explained by the invasive herbivores (GarzónMachado et al. 2010) and human impacts in the past, including cutting, fire or poorly planned plantations (Del Arco et al. 1992, Bello-Rodríguez et al. 2019). On the other hand, the laurel forest stands (with dark and 

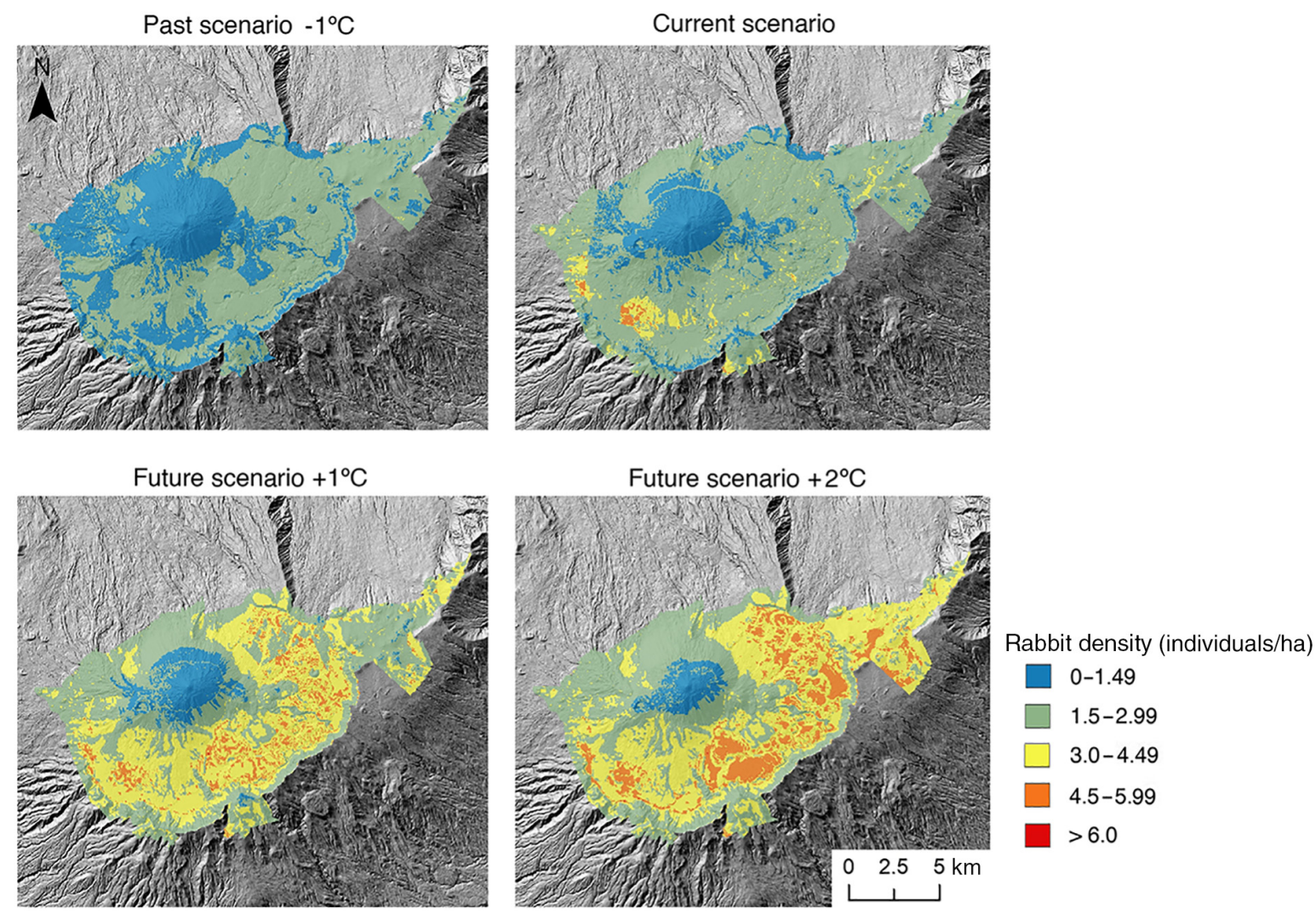

FIg. 3. Spatial distribution of rabbits (individuals/ha) in Tenerife alpine ecosystem during 2017 (current scenario) and projections to past and future scenarios of global warming. [Color figure can be viewed at wileyonlinelibrary.com]

humid conditions), represent the ecosystem with lowest rabbit abundance in the island, as occurs in other similar environments (Norbury and Reddiex 2005, Serronha 2014).

It is important to note that despite the general picture that working at this scale provides, we also found some limitations. For example, we have not considered other local factors such as food resources, characteristics of soil, hunting, or diseases, which could also explain rabbit abundance (Myers and Parkers 1965, Blanco and Villafuerte 1993, Calvete et al. 2005, Cabrera-Rodríguez 2008, López-Darias and Lobo 2009, Tablado et al. 2012, Kontsiosis et al. 2013, Serronha 2014, Martín-Alonso et al. 2016) or the possible effect of local declines in vegetation cover due to extreme desertification (Blanco and Villafuerte 1993, Tablado and Revilla 2012). In fact, we assumed that vegetation remained stable in the different climate scenarios, despite Del Arco (2008) and Del Arco and Garzón-Machado (2012) pointing out that Tenerife ecosystems are also expected to change with elevation as climate changes. However, there is a high degree of uncertainty, since plant species migration may be also highly affected by rabbit browsing. For example, BelloRodríguez et al. (2019) show how rabbit abundance reduces regeneration in the upper limits of the pine forest, especially in the new colonizing areas beyond the treeline, making it difficult for Pinus canariensis to colonize more elevated areas and prolonging the existence of the alpine scrub in most of the current areas. Therefore, invasive herbivores must be taken into consideration as a limiting factor in the expected elevational migration of plant species, in addition to the typical geological and climatic factors of these areas suggested by Höllerman (1978), Gieger and Leuschner (2004), and Brito et al. (2015).

Overall, our results support the idea that rabbits will be an increasing problem on Tenerife island under the expected climate change scenarios, which ultimately will have consequences on its valuable endemic flora. We argue that rabbit pressure could have also strong consequences on the migration capacity of the plant endemics species under climate change. Considering the high cost that suppose the control and eradication of invasive species (Pimentel et al. 2005, Jardine and Sanchirico 2018), we expect that this study will become a valuable tool for the administrations that manage the invasive species on this island to identify priority areas in which perform controls. 


\section{ACKNOWLEDGMENTS}

We are very grateful to Jesús Parada, Severin Irl, Juan Luis Rodríguez Luengo, Raquel Hernández-Hernández and Rafael Villafuerte for their assistance during the fieldwork and especially the latter for his advice about part of the methodology of this study. Funding for the project was provided by the Ministerio de Agricultura, Alimentación y Medio Ambiente (REF $1621 / 2015$ ). We also thank the financial support from the Canary Islands Government through its program of financial support for researchers co-funded in an $85 \%$ by the European Social Fund and the financing granted to Universidad de La Laguna from Consejería de Economía, Industria, Comercio y Conocimiento, co-funded in an $85 \%$ by the European Social Fund.

\section{Literature Cited}

Atkinson, I. A. 1989. Introduced animals and extinctions. Pages 54-69 in D. Wester, and M. C. Pearl, editors. Conservation for the twenty-first century. Oxford University Press, New York, New York, USA.

Atkinson, I., and T. J. Atkinson 2000. Land vertebrates as invasive species on the islands of the South Pacific. Pages 19-84 in G. Sherley, Technical editor. The invasive species in the pacific: a technical review and draft regional strategy. South Pacific Regional Environment Programme (SPREP), Samoa.

Barrera Morate, J. L. and García, M. 2011. Mapa Geológico de Canarias. GRAFCAN, Santa Cruz de Tenerife.

Bello-Rodríguez, V., J. Cubas, M. J. Del Arco, J. L. Martín, and J. M. González-Mancebo. 2019. Elevational and structural shifts in the treeline of an oceanic island (Tenerife, Canary Islands) in the context of global warming. International Journal of Applied Earth Observation and Geoinformation 82:101918

Blanco, J. C., and R. Villafuerte 1993. Factores ecológicos que influyen sobre las poblaciones de conejos: incidencia de la enfermedad hemorrágica. Technical report. Empresa de Transformación Agraria S.A., Madrid, Spain.

Bowen, L., and D. V. Vuren. 1997. Insular endemic plants lack defenses against herbivores. Conservation Biology 11:12491254.

Braojos, J. J. 2015. La nube, el pino y la otra lluvia. Cabildo Insular de Tenerife, Santa Cruz de Tenerife, Spain.

Breiman, L. 2001. Random forests. Machine Learning 45:5-32.

Brito, P., R. Lorenzo, A. M. González-Rodríguez, D. Morales, G. Wieser, and M. S. Jiménez. 2015. Canopy transpiration of a semi-arid Pinus canariensis forest at a treeline ecotone in two hydrologically contrasting years. Agricultural and Forest Meteorology 201:120-127.

Cabezas, S., and S. Moreno. 2007. An experimental study of translocation success and habitat improvement in wild rabbits. Animal Conservation 10:340-348.

Cabrera-Rodríguez, F. 2006. Microhabitat selection of the European rabbit on La Palma, Canary Islands, Spain. Acta Theriologica 51:435-442.

Cabrera-Rodríguez, F. 2008. Seasonal abundance and management implications for wild rabbits (Oryctolagus cuniculus) on La Palma, Canary Islands, Spain. Wildlife Biology 3:39-47.

Calvete, C., E. Angulo, and R. Estrada. 2005. Conservation of European wild rabbit populations when hunting is age and sex selective. Biological Conservation 121:623-634.

Calvete, C., R. Estrada, E. Angulo, and S. Cabezas-Ruiz. 2004. Habitat factors related to wild rabbit conservation in an agricultural. Landscape Ecology 19:531-542.
Chapuis, J. L., Y. Frenot, and M. Lebouvier. 2004. Recovery of native plant communities after eradication of rabbits from the subantarctic Kerguelen Islands, and influence of climate change. Biological Conservation 117:167-179.

Cooke, B. D., and S. R. McPhee. 2007. Rabbits and Native Plant Biodiversity. A report complied for Australian Wool Innovation and Meat and Livestock Australia as part of the Invasive Animals Co-operative Research Centre Project 7.T. 6- Biodiversity Impact of Rabbits. Australia.

Courchamp, F., J. L. Chapuis, and M. Pascal. 2003. Mammal invaders on islands: impact, control and control impact. Biological reviews of the Cambridge Philosophical Society 78:347-383.

Cubas, J., S. D. H. Irl, R. Villafuerte, V. Bello-Rodríguez, J. L. Rodríguez-Luengo, M. J. Del Arco, J. L. Martín-Esquivel, and J. M. González-Mancebo. 2019. Endemic plant species are more palatable to introduced herbivores than non-endemics. Proceedings of the Royal Society B: Biological Sciences 286:20190136.

Cubas, J., J. L. Martín-Esquivel, M. Nogales, S. D. H. Irl, R. Hernández-Hernández, M. López-Darias, M. MarreroGómez, M. J. Del Arco, and J. M. González-Mancebo. 2018. Contrasting effects of invasive rabbits on endemic plants driving vegetation change in a subtropical alpine insular environment. Biological Invasions 20:793-807.

D'Amen, M., J.-N. Pradervand, and A. Guisan. 2015. Predicting richness and composition in mountain insect communities at high resolution: a new test of the SESAM framework. Global Ecology and Biogeography 24:1443-1453.

Del Arco, M. J.2008. La flora y la vegetación canaria ante el cambio climático actual. Pages 105-140inJ. Afonso-Carrillo, editor. Naturaleza amenazada por los cambios en el clima. Actas III Semana Científica Telesforo Bravo. Instituto de Estudios Hispánicos de Canarias, Puerto de la Cruz, Spain.

Del Arco, M. J., and V. Garzón-Machado. 2012. Estudio predictivo de distribución de los pisos de vegetación en Tenerife y Gran Canaria para diferentes escenarios de Cambio Climático. Gobierno de Canarias, Santa Cruz de Tenerife, Spain.

Del Arco, M. J., R. González-Gonzalez, V. Garzón-Machado, and B. Pizarro-Hernández. 2010. Actual and potential natural vegetation on the Canary Islands and its conservation status. Biodiversity and Conservation 19:3089-3140.

Del Arco, M. J., P. L. Perez, O. Rodríguez, M. Salas, and W. Wildpret. 1992. Atlas cartográfico de los pinares canarios, tomo II Tenerife. Gobierno de Canarias, Santa Cruz de Tenerife, Spain.

Del Arco, M. J. et al 2006. Mapa de Vegetación de Canarias. GRAFCAN SL, Santa Cruz de Tenerife, Spain.

Farfán, M. Á., J. M. Vargas, J. C. Guerrero, A. M. Barbosa, J. Duarte, and R. Real. 2008. Distribution modelling of wild rabbit hunting yields in its original area (S Iberian Peninsula). Italian Journal of Zoology 75:161-172.

Fernández-de-Simón, J., F. Díaz-Ruiz, F. Cirilli, F. S. Tortosa, R. Villafuerte, M. Delibes-Mateos, and P. Ferreras. 2011. Towards a standardized index of European rabbit abundance in Iberian Mediterranean habitats. European Journal of Wildlife Research 57:1091-1100.

Fernández-Palacios, J. M., R. Otto, C. Thebaud, and J. Price. 2014. Overview of habitat history in subtropical oceanic island summit ecosystems. Artic, Antarctic, and Alpine Research 46:801-809.

Flux, J. E. C. 2001. Rabbits (Oryctolagus cuniculus) on Ruapehu at $1800 \mathrm{~m}$. New Zealand Journal of Zoology 28:429-430.

Flux, J. E. C., and P. J. Fullagar. 1992. World distribution of the rabbit Oryctolagus cuniculus on islands. Mammal Review 22:151-205. 
Fordham, D. A., H. R. Akçakaya, M. Araújo, and B. W. Brook. 2012. Modelling range shifts for invasive vertebrates in response to climate change. Pages $86-108$ in J. F. Brodie, E. Post, and D. F. Doak, editors. Wildlife conservation in a changing climate. The University of Chicago Press, London, UK.

Garzón-Machado, V., J. M. González-Mancebo, A. PalomaresMartínez, A. Acevedo-Rodríguez, J. M. Fernández-Palacios, M. Del-Arco-Aguilar, and P. L. Pérez-de-Paz. 2010. Strong negative effect of alien herbivores on endemic legumes of the Canary pine forest. Biological Conservation 143:2685-2694.

Gieger, T., and C. Leuschner. 2004. Altitudinal change in needle water relations of Pinus canariensis and possible evidence of a drought-induced alpine timberline on Mt. Teide, Tenerife. Flora 199:100-109.

GRAFCAN. 2012. Mapa Topográfico Integrado https:// www.idecanarias.es/listado_servicios/mapa-topografico-integrado

Höllermann, P. W. 1978. Geoecological aspects of the upper timberline in Tenerife. Canary Islands. Arctic and Alpine Research 10:365-382.

Instituto Geográfico Nacional. 2018. Base Topográfica Nacional 1:25.000 (BTN25), Madrid, Spain.

Irl, S. D., D. E. Harter, M. J. Steinbauer, D. Gallego Puyol, J. M. Fernández-Palacios, A. Jentsch, and C. Beierkuhnlein. 2015. Climate vs. topography-spatial patterns of plant species diversity and endemism on a high-elevation island. Journal of Ecology 103:1621-1633.

Jardine, S. L., and J. N. Sanchirico. 2018. Estimating the cost of invasive species control. Journal of Environmental Economics and Management 87:242-257.

Kontsiotis, V. J., D. E. Bakaloudis, P. Xofis, N. Konstantaras, N. Petrakis, and A. Tsiompanoudis. 2013. Modeling the distribution of wild rabbits (Oryctolagus cuniculus) on a Mediterranean island. Ecological Research 28:317-325.

Kyncl, T., J. Suda, J. Wild, R. Wildová, and T. Herben. 2006. Population dynamics and clonal growth of Spartocytisus supranubius (Fabaceae), a dominant shrub in the alpine zone of Tenerife. Canary Islands. Plant Ecology 186:97-108.

Lees, A. C., and D. J. Bell. 2008. A conservation paradox for the 21st century: the European wild rabbit Oryctolagus cuniculus, an invasive alien and an endangered native species. Mammal Review 38:304-320.

Liaw, A., and M. Wiener. 2002. Classification and Regression by randomForest. $\mathrm{R}$ News $2: 18-22$.

López-Darias, M., and J. M. Lobo. 2009. Micro-scale distribution of rabbits on Fuerteventura Island. Biodiversity and conservation 18:3687-3704.

Lowe, S., M. Browne, S. Boudjelas, and M. De Poorter. 2000. 100 of the world's worst invasive alien species: a selection from the global invasive species database. Volume 12. Invasive Species Specialist Group, Auckland, New Zealand.

Luque, A., J. L. Martín, P. Dorta, and P. Mayer. 2014. Temperature trends on gran canaria (Canary Islands). An example of global warming over the subtropical Northeastern Atlantic. Atmospheric and Climate Sciences 4:20-28.

Marrero, P., and C. Martín. 2000. Spring food preferences of rabbits (Oryctolagus cuniculus L., 1758) on the Islet of Alegranza (Canarian Archipelago). Zeitschrift für Säugetierkunde 65:246-250.

Martín, J. L., J. Bethencourt, and E. Cuevas-Agulló. 2012. Assessment of global warming on the island of Tenerife, Canary Islands (Spain). Trends in minimum, maximum and mean temperatures since 1944. Climatic Change 114:343-355.

Martín, J. L., M. V. Marrero, M. J. Del Arco, and V. GarzónMachado. 2015. Aspectos clave para un plan de adaptación de la biodiversidad terrestre de canarias al cambio climático. Gobierno de Canarias, Santa Cruz de Tenerife, Spain.

Martín, M. C., P. Marrero, and M. Nogales. 2003. Seasonal variation in the diet of wild rabbits Oryctolagus cuniculus on a semiarid Atlantic island (Alegranza, Canarian Archipelago). Acta Theriologica 48:399-410.

Martin-Alonso, A., N. Martin-Carrillo, K. Garcia-Livia, B. Valladares, and P. Foronda. 2016. Emerging rabbit haemorrhagic disease virus 2 (RHDV2) at the gates of the African continent. Infection, Genetics and Evolution 44:46-50.

Mateo, R. G., et al. 2016. The mossy north: an inverse latitudinal diversity gradient in European bryophytes. Scientific Reports 6:25546.

Mutze, G., B. Cooke, M. Lethbridge, and S. Jennings. 2014. A rapid survey method for estimating population abundance of European rabbits living in native vegetation. Rangeland Journal 36:239-247.

Mutze, G., Cooke, B., and Jennings, S. 2016. Estimating density-dependent impacts of European rabbits on Australian tree and shrub populations. Australian Journal of Botany 64:142.

Myers, B. K., and B. S. Parker. 1965. A study of the biology of the wild rabbit in climatically different regions in Eastern Australia, 1 Patterns of distribution. CSIRO Wildlife Research 10:1-32.

Norbury, G., and B. Reddiex. 2005. European rabbit. Pages 5680 in C. M. King, editor. Handbook of New Zealand mammals. Second edition. Oxford University Press, Melbourne, Victoria, Australia.

Otto, R., B. O. Krüsi, and F. Kienast. 2007. Degradation of an arid coastal landscape in relation to land use changes in Southern Tenerife (Canary Islands). Journal of Arid Environments 70:527-539.

Pimentel, D., R. Zuniga, and D. Morrison. 2005. Update on the environmental and economic costs associated with alien-invasive species in the United States. Ecological Economics 52:273-288.

R Core Team. 2011. R: A language and environment for statistical computing. R Foundation for Statistical Computing, Vienna, Austria. https://www.R-project.org/

Regos, A., L. Tapia, M. Vidal, and J. Domínguez. 2012. Teledetección y SIGs como fuentes de información ambiental en el modelado de distribución de especies: el caso práctico del Conejo europeo. XV Congreso Nacional de Tecnologías de la Información Geográfica, 19-21. AGE-CSIC, Madrid.

Rodríguez-Piñero, J. C., and J. L. Rodríguez-Luengo.1993. The effect of herbivores on the endemic Canary flora. Boletim do Museu Municipal do Funchal, Sup N 2, 265-271.

Rouco, C., S. Santoro, M. Delibes-Mateos, and R. Villafuerte. 2016. Optimization and accuracy of faecal pellet count estimates of population size: The case of European rabbits in extensive breeding nuclei. Ecological Indicators 64:212-216.

Santana, B., and J. Martín. 2013. Catálogo de mapas climáticos de Gran Canaria y Tenerife-Tomos 2 y 5. Proyecto ClimaImpacto MAC/3/159. Gobierno de Canarias, Las Palmas de Gran Canaria.

Serronha, A. M. 2014. Modeling the factors limiting the distribution and abundance of the European rabbit (Oryctolagus cuniculus) in SE Portugal. Thesis. Universidade de Évora, Évora.

Steinbauer, M. J., et al. 2016. Topography-driven isolation, speciation and a global increase of endemism with elevation. Global Ecology and Biogeography 25:1097-1107.

Tablado, Z., and E. Revilla. 2012. Contrasting effects of climate change on rabbit populations through reproduction. PLoS ONE 7:e48988. 
Tablado, Z., E. Revilla, and F. Palomares. 2012. Dying like rabbits: general determinants of spatio-temporal variability in survival. Journal of Animal Ecology 81:150-161.

Tapia, L., J. Domínguez, A. Regos, and M. Vidal. 2014. Using remote sensing data to model European wild rabbit (Oryctolagus cuniculus) occurrence in a highly fragmented landscape in northwestern Spain. Acta Theriologica 59:289-298.
Trout, R. C., S. Langton, G. C. Smith, and R. H. HainesYoung. 2000. Factors affecting the abundance of rabbits (Oryctolagus cuniculus) in England and Wales. Journal of Zoology 252:227-238.

Villafuerte, R., and M. Delibes-Mateos. 2002. Oryctolagus cuniculus (Linnaeus, 1758). Atlas de los mamíferos terrestres de España. Dirección General de Conservación de la Naturaleza. SECEM-SECEMU, Madrid, Spain.

\section{SUPPORTING INFORMATION}

Additional supporting information may be found online at: http://onlinelibrary.wiley.com/doi/10.1002/eap.2206/full

\section{Data Availability}

Data are available on Figshare: https://doi.org/10.6084/m9.figshare.9931370 